\title{
Possession Behaviour
}

\section{Vagrecha YS*}

School of Psychology, College of Education and Behavioral Studies, Addis Ababa University, Ethiopia

\begin{abstract}
'Possession' has been observed in many forms and in many countries, especially in rural communities, country sides, in poor, uneducated, marginalized and tribal population, but in urban areas and metropolitan cities as wellin their slums and higher societies. It has been reported extensively by anthropologists, sociologists and lately by psychologists. To understand dynamics of such behaviour needs enormous and extensive resources, time, patience and passion. Why people are possessed? What are their conflicts and psychological needs? How it is resolving and serving them? Why surrounding community believe it? And why it became their way of life? To answer these questions:
\end{abstract}

First we will deal with possession behaviour in its totality to have a fuller understanding of such phenomenon, than Purvaj Syndrome will be presented in brief, a possession phenomenon of helping nature investigated by the author in a rural community in India.

Keywords: Possession; Purvaj syndrome; Possession behavior; Epidemiology

\section{Possession Behavior}

- An age-old phenomenon observed all over the world.

- $\quad$ An episodic disruption of behaviour during which Person's personality being replaced by a human or animal spirit or by God / deity/devil or spirit of inanimate object.

- Whose characteristics are well known within the person's culture who impersonates it.

\section{Possession}

- $\quad$ Possession may be of an Individual or Group as a whole.

- It may be of bad spirits or good spirits.

- Possession may be voluntary or involuntary.

- It may be considered to have beneficial or detrimental effects.

- It may be unconscious, preconscious, semiconscious or sometimes purely a conscious process (malingering only).

- Such behaviour can be misinterpreted representing as Neurological or Psychiatric disorders and inappropriate diagnosis and treatment may be given.

- $\quad$ Sometimes, if medical help is sought, physician may over pathologies, subjecting person with heavy doses of tranquilizers.

- To deal with such behaviour, psychologists should not brush off rituals based upon experience of cultures over centuries of time, with many bright insightful healers. Can psychologists learn something from them? In Warsa, Poland there is a clinic who has employed a Shaman on its regular staff.

\section{Possession behavior in the following sub headings}

- $\quad$ Epidemiology

- $\quad$ Spirit Possession

- Trance

- Dissociative Behavior
- Mental Illness

- General Symptoms

- Differential Diagnosis

- Culture Bound Syndrome

- Religion and Possession Cult

- Some instances of possession behavior worldwide

- Examples of proactive possession behavior in Africa

- Causation

- Dynamics I

- Dynamics II

- Purvaj syndrome

\section{Epidemology}

- In a survey, Bourgignon found 488 Societies have Institutionalized, culturally patterned form of Altered State of Consciousness. In 252 such experience was attributed to possession.

- In a survey in an Indian State of 1158 Households, 3.7\% spirit possession was troublesome, but God/helpful possession exceeded the above percentage.

- Cross-culturally more common among women than men, but men are catching-up as in migrant Ethiopian men in Israel more exhibiting Zar Possession.

- Young age, low education, repressive social order predisposes

*Corresponding author: Vagrecha YS, School of Psychology, College of Education and Behavioral Studies, Addis Ababa University, Ethiopia, Tel: +251 912308056; E-mail: ysvagrecha@yahoo.com

Received May 31, 2016; Accepted June 20, 2016; Published June 24, 2016

Citation: Vagrecha YS (2016) Possession Behaviour. Abnorm Behav Psychol 2 119. doi: $10.4172 / 2472-0496.1000119$

Copyright: ( 2016 Vagrecha YS. This is an open-access article distributed under the terms of the Creative Commons Attribution License, which permits unrestricted use, distribution, and reproduction in any medium, provided the original author and source are credited. 
people to have possession behaviour.

\section{Spirit possession}

- $\quad$ Spirit possession is believed to be paranormal or supernatural event in which it is said that animals, demons, gods, extraterrestrials ,inanimate objects or good and bad spirits etc. take control of human body for the time being (transitory),resulting in noticeable changes in health and behaviour of the possessed person.

\section{Trance}

- $\quad$ Trance is characterized by a transient alteration in identity whereby one's normal identity is temporarily replaced (possessed) by a spirit, ghost, deity or other person, animals or inanimate objects (author has observed the possession of persons by so called spirit(s) of the holy river Ganges and of a Fort where battles have been fought for centuries).

\section{Dissociative behavior}

- In scientific psychology 'Possession' is not recognized as psychiatric disorder deserve for medical diagnosis. It was placed under general rubric of dissociative disorders. (ICD-10 -F 44.3, Trance and Possession Disorders/DSM-IV-300.15 Dissociative Disorders).

- Dissociative identity disorders, Multiple personality, demonomania, demopathy or monomania are other names in vogue.

\section{Mental illness}

- $\quad$ People with weak boundaries and low self-esteem having dysfunctional ego may exhibit possession behaviour. Mostly due to psychological causes, but brain damage may also be a causal factor.

- $\quad$ Sometimes they exhibit symptoms similar to those associated with mental illness such as psychosis, hysteria, mania, epilepsy, schizophrenias etc.

\section{General symptoms}

- A few or more following symptoms may be witnessed in the 'possessed' persons who may be mild, moderate or severe in other words they may be sober or violent.

- Loss of control over one's actions.

- Behaviour change or acting differently.

- Loss of personal identity /altered state of consciousness.

- Change in tone of voice as if a different person is speaking.

- Wandering attention/trouble in concentrating.

- $\quad$ Reality mixed with fantasy.

- Loss of awareness of surroundings.

- Loss of sense of time.

- Belief that one's body changes in appearance.

- $\quad$ Feeling of omnipotence/all powerfulness.

- Loss of memory of trance session.

- $\quad$ Sometimes body hopping by the medium (in a violent way).

\section{Differential diagnosis}

- Dementia

- Delirium
- Major Depression / Mania

- $\quad$ Post-Traumatic Stress Disorder

- $\quad$ Head Trauma - Temporal \& Frontal Lobe Lesions

- Schizophrenia(s)

- Alcoholism

- $\quad$ Epilepsy

- Dissociative Identity Disorder/ Hysteria / Multiple personality

- Tourette Syndrome

- $\quad$ Malingering

Culture bound syndrome

- Cultural Anthropologists were first to observe and report possession behaviour. Psychologists arrived late on the scene.

- It hold different meaning in different cultures, therefore, it is culturally bound.

- Spirit possession is a culturally sanctioned, heavily institutionalized and symbolically invested means of expression in action for various ego-dystonic impulses and thoughts.

- Possession by good spirits are often accepted as normal in most of the cultures, possessed individual even achieve status of being seen having healing power, understanding and wisdom.

- Possessions by bad spirits are often feared and family members seek help in culturally sanctioned way to cast the evil spirit out from the body of possessed person.

\section{Religion and possession cult}

- Concept of Spirit possession exists in many religions including Christianity, Islam, Buddhism, Hinduism as well as in Latin American, South East Asian and African traditions.

- Local Possession Cult and spreading religion have reciprocally influenced each other and altered their rituals.

- Both side cooperated, but also in rivalry and often 'conflicts' emerged in a tug of war for 'power possession'.

\section{Some instances of possession behaviour worldwide}

- Zar possession in Ethiopia, Sudan and Israel.

- Gurage people in Ethiopia- due to food anxiety.

- Sidama women in Ethiopia- for luxury goods.

- Digo women in Kenya- Shaitani - for Luxury goods.

- Mozambique- Spirits of dead soldiers in civil war.

- $\quad$ South Africa- married women-ability to foretell the future.

- China- Spirits of animals.

- India-Spirit of murdered Royalty in war, Sati, ancestral souls, bad spirits like Bhut, Dakin, Chudail, Jinn and soul of snakes, fort etc. Young girls and women are victims.

- Malaysia- Female workers in the factory.

- Christianity- Angels, fallen angels and demons. 
- $\quad$ Muslims- Saitan, Jinn and bad Ruh.

\section{Examples of proactive possession behavior in Africa}

- Madagascar 'Tromba' spirit mediums (women) were a vital force in social and economic transformation/national development projects.

- Role of Spirits (Mediums) during Liberation war in Zimbabwe and Mozambique.

- In 1986 the spirit of Lekwena and its 'Holy Spirit Mobile Force (HSMF)' wage a war against government in Uganda.

- In Gwembe valley, Zambia there was a tug of war between dominant 'Bori' spirits who favoured capitalist Market Economy and newly invented 'Dodo spirits' who were pro-social and against capitalist Market economy and modern consumerism.

- To some extent Swahili coast of Kenya and a few instances of Zar possession in Sudan have similar inferences.

- In Africa spirit possession is used as resistance and empowerment of women, denaturalizing male hegemonies and even to challenge and appropriate male power.

\section{Causation}

- Multi factorial- spiritual, social, psychological, economical, physical and cultural.

- Intra psychic explanation- is due to repressed negative feelings/compensatory behaviour.

- Physical anthropologists say it is due to deficiency of thiamine, calcium, vitamin D, affecting Nervous System in women.

- Vicarious learning since childhood, vulnerable persons resort to such practices.

- Voluntary possession-high priestess solicits the Goddess.

- Sometimes it is for explicit or implicit sexual solicitation and erotic pleasure.

- Unconsciously it is a 'tug of war' between haves and haves not.

- More dynamic reasons are being stated elsewhere in this article.

\section{Dynamics-I}

- Spirit possession is not a Pre-Modern or Traditional phenomenon or exists in primitive societies or in tribal and rural areas only. Possession cults are proliferating the world over, not only in Africa, Asia and Latin America but in such modern cities as New York, Toronto, Paris and Cologne.

- Comprehension of this complex phenomenon will add to our understanding that how through a Medium people are able to reflect upon a wide range of issues which concern them.

- Spirit possession cults are not to be seen in isolation; instead they are to be seen in a wider field of power relations with various competing discourses, practices and forces. Rivalry and opposition between different spirits and to include foreign spirits in to local is part of the same power game.

- One view is that possession is a marginal experience of weak and powerless. It is a 'safety valve' mechanism that enables those occupying subordinate social status to assert them temporarily without being held responsible for their actions. Logic being that the possessing spirit and not the individual, is responsible for any words uttered or deeds committed during trance [1].

- Marginalized people- whether psychologically, socially, economically, politically, gender wise or in many other ways vent their pent up emotions in a different language which needed to be decoded.

- Rapid industrialization, urbanization and modernization having fast pace of life have left many people and sections of the society far behind, where they suffer from alienation, helplessness and suffocation. Human being and societies are dynamic entities. They cannot remain in a status quo for a prolonged time. They invent ways and means to express themselves and to readdress their grievances in their own specific way.

\section{Dynamics-II}

- A few researchers have questioned these pervasive assumptions, insisting that possession may be a Central, rather than marginal cultural phenomenon.

- In African context, possession cult and behaviour have been observed and recorded not only in context of intra psychic conflicts and interpersonal imbalances but also in initiating a proactive and pro social behaviour.

- Contribution of spirits through their mediums in Africa in the process of modernization, to developmental projects, their involvement in modern warfare, their support or critique to capitalist market economy, their fight against evil and their empowerment of women and former slaves are a few out of many examples which demonstrate their central role in a proactive manner rather than remaining only a marginal entity.

\section{Purva jsyndrom}

(Ancestral soul Phenomenon investigated and reported by the author)

- It is a distinct form of Mediumistic Trance Behaviour (MTB) in which a recently deceased member of family (Purvaj) is impersonated by a living marginalized member in a joint family system, and not a god, deity or spirit by the mediums, as common in many other forms of possession and shamanistic trance behaviour.

- It is considered to be of a 'helping' nature and has been reported rarely.

- It is a specific kind of MBT found in a rural community of Rajasthan state in India and is a culture bound reaction to a stress situation when it begins in the life of a person, in the process it works as a community medicine and in the end it leads to normalcy after a few years of practicing it.

\section{Observations}

From my childhood and during the investigation it was observed that quite a few males/females exhibit 'possession' behaviour, characterized by spasmodic, rhythmic and vigorous bodily movements, at times accompanied by violent jerks, screaming and certain mannerism like husky voice etc.

- This commences with yawning, followed by deep breathing, unconscious imitation of the voice and conversation style of an individual who had died recently in the family.

1. The 'possession' state last for about 25 to 30 minutes in which the family 'medium' assumes the role of the deceased person and impersonates him like a local Shaman during trance. He consoles, 
advises and assures help and protection during this trance, at the time of any eventuality that may be fall the family in present or in time to come [2].

2. These attacks have some kind of periodicity and occur voluntarily or involuntarily in any stress situation in the family.

\section{Belief}

- It is generally believed in the rural community that the cause of some trouble, illness or misfortune in the family is due to wandering soul of recently deceased family member who could not get liberation due to its deep attachment with family members. Now it wants solace and institutionalization. If family wants to get rid of its troubles.

\section{Forewarning signals}

Forewarning signals that wandering soul is causing trouble

- $\quad$ Milk is getting sour on recurrent days.

- $\quad$ Milch cows and buffaloes ceasing to give milk.

- Illness/death of domestic animals, cow, bullock.

- $\quad$ Frequent quarrels in the (joint) family.

- Dispute with residence/farm neighbours.

- $\quad$ Failure of the crop.

- Illness or accident in the family.

- Vague pains in the body, stomach, legs or head of some family members, still birth or abortion.

- Litigation, economic hardship or any other trouble.

\section{Dreams}

- The above episodes coincide or followed by dreams to one of the family members.

- In these dreams departed soul ask for worship and recognition as it wants solace and peace.

- In return it promises harmony, peace, prosperity and trouble free atmosphere in the family.

- It is also instructed that an engraved image of the departed is to be worn around neck by someone, or it is to be worshiped on occasions.

\section{Tug of war and consultations}

- $\quad$ Some family members resist it, however the most vulnerable person whose unconscious eyes constantly watch these developments, suddenly and frequently goes into trance, and ultimately family yield to the situation.

- They also consult local Shamans who confirm the appearance of Purvaj in the family.

- Finally decision is taken to institutionalise the Purvaj.

\section{Institutionalization}

- $\quad$ On any of the two full moon days, at the end of a six month cycle, coinciding with the reaping of winter or summer harvest, with family, friends, neighbours and relatives, with festivity, feast and fun Purvaj are worshiped and established. Ladies sing the songs in praise of Purvaj the whole night and ask them to bestow their blessings on the family. They are remembered later on occasions like marriage in the family or on any festival day. Respect of the marginalized family member who get into trance also get enhanced and s/he no longer taunted or seen as inferior person.

\section{Controlled investigation}

A project was submitted which was approved and funded by Indian Council of Medical Research.

\section{Hypotheses}

1) Purvaj Syndrome (MBT) is a Culture -bound reaction to stress.

2) There will be a significant difference between Experimental and Control Groups on their stress scores (scores on Stress check list and Neuroticism scale).

3) With the ascending years of practicing Purvaj (MBT) there will be proportionate descending trend in their stress scores.

\section{Results and Conclusion}

Research data confirmed the above hypotheses. After practicing the Purvaj (trance) for a few years, the trance behaviour either diminished, weaken or disappeared in the medium as marginalized family member improved his/her position in the family and in the community during the period of practicing the trance.

\section{References}

1. Lesley A Sharp (1999) Spirit Possession: spirit possession, modernity and power in Africa. University of Wisconsin.

2. Vagrecha YS, Asthana HS (2002) Purvaj Syndrome: a culture bound reaction to stress and a psychotherapeutic device. Psychological Studies 47: 91-99. 